\title{
Formasi kelompok dinamis untuk mendukung kolaborasi pembelajaran proyek perangkat lunak
}

\author{
Danang Wahyu Utomo *, Defri Kurniawan \\ Fakultas Ilmu Komputer, Universitas Dian Nuswantoro. \\ Jalan Imam Bonjol No. 207, Pendrikan Kidul, Semarang, Jawa Tengah 50131, Indonesia. \\ danang.wu@dsn.dinus.ac.id \\ * Corresponding Author
}

\section{ARTICLE INFO}

\section{Article History}

Received:

26 April 2020;

Revised:

10 July 2020;

Accepted:

7 August 2020

Keywords

Rekayasa perangkat

lunak;

Pembelajaran

kolaboratif;

Dynamic group

formation;

Algoritma genetika;

Software engineering;

Collaborative learning.

Genetic algorithm

\begin{abstract}
Matakuliah proyek perangkat lunak digunakan untuk melatih mahasiswa dalam penguasaan materi pengembangan perangkat lunak yang terdiri dari analisis, desain, implementasi, dan evaluasi. Mahasiswa diajarkan bagaimana cara mengerjakan perangkat lunak dari tahap awal hingga tahap akhir. Selain itu, mahasiswa juga dilatih untuk bekerja secara tim. Permasalahan yang terdapat pada Universitas Dian Nuswantoro adalah pembentukan kelompok masih dilakukan secara random-select. Pembentukan kelompok yang dilakukan mahasiswa berdasarkan unsur pertemanan, satu komunitas, atau grup di social media seperti WhatsApp. Hasilnya, terjadi ketidakseimbangan di dalam kelompok tim proyek. Ketidakseimbangan tim proyek dapat menyebabkan gagalnya proyek pengembangan perangkat lunak. Penelitian ini mengusulkan eksperimen pendekatan dynamic group formation dengan algoritma genetika. Hasil dari eksperimen menunjukkan bahwa algoritma genetika mampu membantu pembentukan kelompok tim proyek dengan tingkat keberhasilan $87.5 \%$ dengan pengaturan inisial populasi adalah 100 populasi dan probabilitas crossover adalah 0.6. Tujuan dari penelitian ini adalah memberikan alternatif pembentukan kelompok mahasiswa secara dinamis guna mendukung kolaborasi tim proyek mahasiswa. Pada proyek perangkat lunak kedepan, tidak ada pembentukan tim proyek secara homogen atau pemilihan anggota tim proyek secara self-select atau random-select.
\end{abstract}

Software project courses are used to train students in mastering software development materials consisting of analysis, design, implementation, and evaluation. Students are taught how to work on software from the initial stage to the final stage. In addition, students are also trained to work in teams. The problem in Universitas Dian Nuswantoro is that group formation is still done randomly-selectively. The formation of groups by students is based on the friendship level, a community, or a group on social media such as WhatsApp. As a result, there is an imbalance in the project team. Imbalance of the project team can cause the failure of software development projects. This study proposes an experiment using a dynamic group formation approach with genetic algorithms. The results of the experiment show that the genetic algorithm is able to help the formation of project team groups with a success rate of $87.5 \%$ with the initial population is 100 population and the probability of crossover $(\mathrm{pc})$ is 0.6. The objective of this study is to provide an alternative dynamic formation of student groups to support the collaboration of student project teams. In the future, there is no homogeneous project team formation or selection of member teams using a self-select or random-select method.

This is an open access article under the CC-BY-SA license.

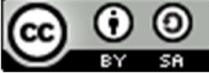




\section{PENDAHULUAN}

Proyek Perangkat Lunak (PPL) adalah bagian penerapan dari matakuliah rekayasa perangkat lunak. Pada Universitas Dian Nuswantoro, matakuliah PPL mengarahkan mahasiswa dalam proyek pengembangan perangkat lunak yang akan diaplikasikan ke industri, perusahaan, pemerintahan, atau sekolah. Mahasiswa diharapkan mampu menerapkan semua tahap pengembangan perangkat lunak, metode dan alat dalam mengembangkan perangkat lunak dan mampu berkolaborasi dan bekerja sama dengan mahasiswa lainnya sebagai tim. Utomo menyatakan bahwa kerja kolaborasi antar mahasiswa pemula dapat meningkatkan komunikasi tim menjadi interaktif dan melatih tanggung jawab mahasiswa dalam mengerjakan deskripsi tugasnya selama proyek pengembangan perangkat lunak berlangsung (Utomo, Kurniawan, \& Sani, 2020).

Pada level strata-1 (sarjana), proses pembelajaran pada matakuliah PPL adalah menerapkan tahapan SDLC dalam mini proyek yang telah ditentukan oleh instruktor (dosen pengampu). Mahasiswa belajar dalam menganalisis permasalahan yang ditemukan, merancang suatu pemodelan sebagai acuan dokumentasi dalam tahap implementasi dan memilih metode dan alat yang tepat untuk digunakan dalam pengembangan proyek perangkat lunak. Selain itu, mahasiswa juga dituntut untuk melakukan kerja kelompok dengan mahasiswa lain meskipun berbeda angkatan. Dalam hal ini, mahasiswa dilatih untuk bekerja secara tim, bagaimana memberikan pendapat dalam tim, mengusulkan metode dan alat kepada tim.

Secara umum rekayasa perangkat lunak adalah disiplin ilmu yang yang dilakukan oleh individu-individu dengan pengalaman dan latar belakang pengetahuan yang berbeda dalam satu tim (Dascalu, Dumitrache, Coman, \& Moldoveanu, 2015). Masing-masing individu bekerja secara individu berdasarkan bagian tugas deskripsinya, namun tetap melakukan koordinasi secara rutin untuk menentukan hasil produk (perangkat lunak) yang dirancang. Bagi mahasiswa pemula, kerja tim dapat meningkatkan kemampuan komunikasi dan tanggung jawab dalam proyek. Largent menyatakan bahwa mahasiswa computer science seharusnya diarahkan pada kerja tim untuk meningkatkan softskill siswa seperti kemampuan verbal, pemecahan masalah, dan manajemen waktu (Largent, 2016).

Permasalahan yang dihadapi dalam pembelajaran proyek perangkat lunak adalah pembentukan kelompok tim proyek. Dalam matakuliah proyek perangkat lunak terdiri dari mahasiswa dengan angkatan yang berbeda-beda. Masih terdapat gap antara mahasiswa senior dengan mahasiswa junior. Mahasiswa senior enggan membaur dengan mahasiswa junior. Hal ini menjadi faktor utama proses pembentukan kelompok tim proyek masih dilakukan dengan self-select, yaitu mahasiswa memilih sendiri anggota tim proyek. Ketua komting kelas membagi kelompok hanya berdasarkan jumlah mahasiswa dibagi dengan jumlah tim yang akan dibentuk, atau masing-masing mahasiswa diberi kebebasan memilih temannya untuk dijadikan satu tim. Pada Universitas Dian Nuswantoro, sebagian besar mahasiswa melakukan pemilihan anggota tim berdasarkan unsur pertemanan, misalnya teman satu komunitas, grup sosial media (WhatsApp), atau satu anggota dalam game MOBA. Jika metode ini diterapkan pada pembentukan tim proyek perangkat lunak maka akan menghasilkan anggota tim yang tidak berimbang. Ada tim yang jumlahnya lebih sedikit dibanding tim lain, ada beberapa mahasiswa yang tidak masuk kedalam tim karena tidak kenal dengan mahasiswa lainnya, atau tidak berada dalam satu komunitas. Komposisi tim proyek yang tidak berimbang dapat menyebabkan kurang interaktifnya diskusi tim proyek

Penelitian-penelitian terkait telah banyak diusulkan untuk memberikan solusi terbaik terhadap permasalahan pembentukan tim dalam pembelajaran kolaborasi. Beberapa penelitian terkini yang telah diusulkan seperti, 1.) Dynamic group formation (Wijaya, Utomo, \& Kurniawan, 2019; Rahman, Roy, Thirumuruganathan, Amer-Yahia, \& Das, 2019; Amara, Macedo, Bendella, \& Santos, 2016); 2.) Blended learning (Tseng, 2016; Pedersen, Kuran, Frick, \& Mank, 2016; Yamagata-Lynch, 2000); 3.) E-learning (Rahmawati \& Narsa, 2019; Yunis \& Telaumbanua, 2017; Utomo, Subhiyakto, \& Ahmad, 2015), dan 4.) Pengembangan aplikasi pembelajaran kolaborasi (collaborative learning) (Dascalu, Dumitrache, Coman, \& Moldoveanu, 2015; Vivian, Tarmazdi, Falkner, Falkner, \& Szabo, 2015; Wu, 2019). Masing-masing penelitian yang telah diusulkan dapat dikategorikan sebagai berikut: 1.) Metode: penelitian yang mengusulkan praktek atau eksperimen dalam pembentukan kelompok; 2) Teknik: penelitian yang membahas tentang teknik dalam pembentukan kelompok. 
Biasanya teknik komputasi diusulkan dengan melibatkan algoritma; dan 3.) Tool: penelitian yang mengusulkan alat berupa aplikasi dengan menerapkan algoritma khusus pembentukan kelompok. Beberapa penelitian ada yang memperbaiki aplikasi dengan menambah beberapa modul pada aplikasi. Kontribusi tersebut mampu memberikan solusi atas permasalahan - permasalahan dalam pembentukan kelompok.

Hanya saja, metode, teknik atau tool yang diusulkan masih berfokus bagaimana membagi siswa kedalam kelompok kerja baik secara online maupun offline. Untuk meningkatkan kemampuan komunikasi siswa dan kerja kolaborasi antar mahasiswa dibutuhkan suatu pendekatan yang mampu membagi kelompok secara dinamis. Dalam hal ini, dinamis adalah mahasiswa dapat berkelompok dengan siapapun tanpa memperhatikan unsur pertemanan. Jadi, pada setiap penugasan, mahasiswa akan memiliki kelompok yang berbeda. Mahasiswa diharapkan mampu bekerja secara sportif dan interaktif dengan siapapun meskipun dengan mahasiswa asing (tidak dikenal).

Salah satu pendekatan yang saat ini relevan dengan pembentukan kelompok secara dinamis adalah dynamic group formation. Pendekatan ini memungkinkan instruktor untuk membentuk tim secara adil dengan komposisi atau karakteristik yang digunakan. Misalnya, pembentukan kelompok berdasarkan rangking siswa di kelas, pembentukan kelompok berdasarkan karakteristik tipe belajar, atau pembentukan kelompok secara homogeneous atau heterogeneous. Peran instruktor sangat dibutuhkan untuk menentukan komponen atau karakteristik yang digunakan dalam pembentukan tim. Sebagai contoh, pembentukan kelompok untuk mahasiswa pemula tidak dapat menggunakan karakteristik tipe belajar, pengalaman atau pembentukan berdasarkan homogeneous atau heterogeneous. Bagi mahasiswa yang minim pengalaman dan pengetahuan di bidang tertentu akan merasa minder untuk melakukan kerja kelompok. Mahasiswa pemula akan menghindari kerja kelompok karena kurangnya kemampuan berkomunikasi dengan anggota lain. Jika pembentukan kelompok menerapkan karakteristik tipe belajar, maka kerja kelompok kurang kondusif, karena mahasiswa lebih memilih kerja secara individu.

Salah satu kontribusi dalam pembentukan kelompok adalah teknik. Teknik komputasi berupa algoritma dapat membantu pembentukan kelompok secara imbang. Beberapa algoritma mampu memberikan solusi optimal dalam pembentukan kelompok. Penelitian sebelumnya telah mengusulkan berbagai algoritma dalam pembentukan kelompok, diantaranya adalah 1.) Algoritma genetika (Lambora, Gupta, \& Chopra, 2019); 2.) Ant colony (Fahmi \& Nurjanah, 2018); dan 3.) Discrete PSO (Zheng \& Pinkwart, 2014). Penelitian ini menerapkan algoritma genetika sebagai optimasi pembentukan kelompok tim proyek perangkat lunak secara dinamis. Pembentukan kelompok menggunakan hasil akhir mahasiswa pada penugasan SKPL saat mengambil matakuliah rekayasa perangkat lunak Lanjut. Tahap awal percobaan menentukan jumlah alternative populasi yang sesuai, tingkat crossover dan mutation. Pada tahap akhir, proses evaluasi dilakukan untuk mengetahui solusi terbaik dalam pembentukan kelompok secara dinamis. Tujuan utama eksperimen ini adalah memberikan alternatif pembentukan kelompok pada tim proyek mahasiswa dalam matakuliah proyek perangkat lunak. Pada proyek perangkat lunak kedepan, tidak ada pembentukan kelompok tim proyek secara homogen, self-select (pemilihan anggota tim berdasarkan komunitas, kelompok bermain atau grup sosial media).

\section{METODE}

Algoritma genetika adalah algoritma pencarian yang memberikan solusi optimal terhadap kemungkinan-kemungkinan yang terjadi. Mekanisme pencarian menggunakan proses secara genetic (alamiah). Tahap eksperimen terdiri dari penentuan populasi, seleksi dengan nilai fitness, penentuan crossover dan mutasi, penyeleksian individu terbaik, dan populasi baru. Pada Gambar 1, menunjukkan urutan proses eksperimen dimulai dari penentuan populasi hingga menghasilkan populasi baru. Populasi baru akan diperoleh jika menghasilkan individu terbaik dan hasil nilainya adalah optimal. Pengukuran optimal suatu populasi menggunakan nilai fitness.

Inisial populasi adalah penentuan jumlah individu yang akan digunakan pada tahap awal algoritma genetika. Penelitian ini melibatkan mahasiswa program studi Teknik Informatika Universitas Dian Nuswantoro yang telah mengambil matakuliah proyek perangkat lunak. Penelitian melibatkan 40 mahasiswa. Tahap awal eksperimen, mahasiswa dibagi secara random yang 
ditentukan oleh pengajar. Jumlah anggota dalam kelompok adalah 5 anggota. Sebagai contoh, jika kelas A terdapat 40 mahasiswa maka jumlah kelompok adalah 8 kelompok. Inisial populasi ditentukan dengan jumlah 100 populasi.

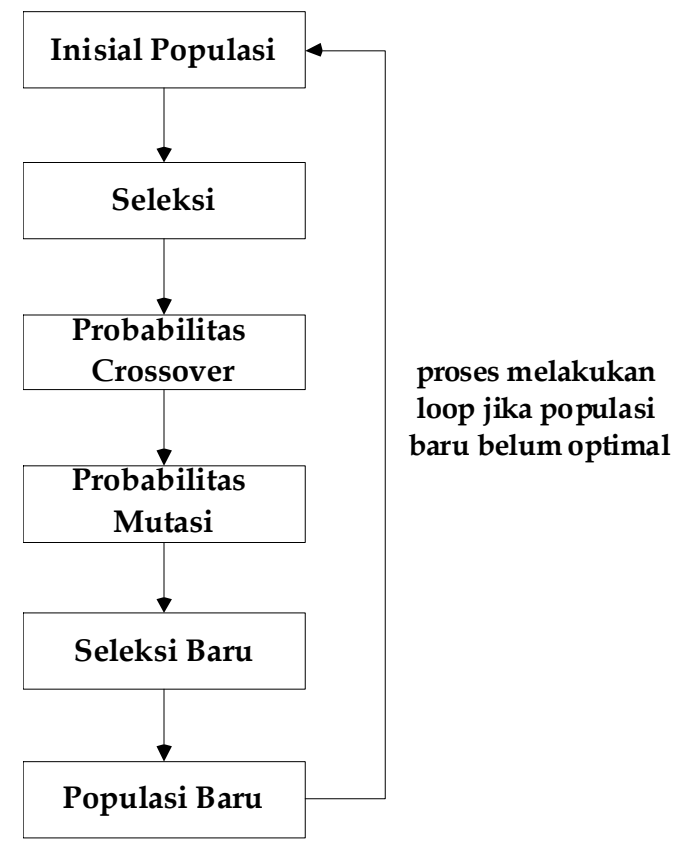

Gambar 1. Tahap Eksperimen

Seleksi adalah proses pemilihan individu terbaik dari individu - individu yang ditentukan pada inisial populasi. Proses seleksi berupa penghitungan nilai fitness tiap kelompok. Berikut formula penghitungan nilai fitness.

$$
\frac{x_{i}}{\sum_{i=1}^{n=3} x_{i}}
$$

Keterangan:

$\boldsymbol{x}_{\boldsymbol{i}} \quad$ : jumlah mahasiswa pada kategori "Baik/Sedang/Kurang".

$\sum \boldsymbol{x}_{\boldsymbol{i}} \quad$ : jumlah keseluruhan siswa pada kategori "Baik/Sedang/Kurang".

Pada rumus atau persamaan (1), formula menghitung jumlah persebaran minimum siswa pada kelompok tim proyek berdasarkan tiap kategori. Artinya, tiap kelompok memiliki jumlah minimum siswa di kategori baik, kategori sedang dan kategori kurang. Penentuan kategori baik, sedang, dan kurang didasarkan pada Tabel 1.

Tabel 1. Kategori Nilai Siswa

\begin{tabular}{lll}
\hline $\mathrm{i}$ & Nilai Huruf & Kategori Nilai \\
\hline 1 & $\mathrm{~A}, \mathrm{AB}$ & Baik \\
2 & $\mathrm{~B}, \mathrm{BC}$ & Sedang \\
3 & $\mathrm{C}, \mathrm{D}, \mathrm{E}$ & Kurang \\
\hline
\end{tabular}

Berdasarkan Tabel 1, dapat diketahui bahwa pnghitungan jumlah minimum siswa jika $\mathrm{i}=1$ maka formula menghitung jumlah siswa pada kategori baik. Jika $\mathrm{i}=2$ maka formula akan menghitung 
jumlah siswa kategori sedang dan seterusnya. Tahap awal eksperimen, kelompok telah dibentuk oleh instruktor secara acak dan diperoleh nilai fitness yang dapat dilihat pada Tabel 2.

Tabel 2. Nilai Fitness Formasi Kelompok Acak Kelas-1

\begin{tabular}{llc}
\hline Kelompok & Anggota & Nilai Fitness \\
\hline Kelompok 1 & {$[10][2][33][19][13]$} & 0.30 \\
Kelompok 2 & {$[3][6][9][1][40]$} & 0.31 \\
Kelompok 3 & {$[21][30][16][31][12]$} & 0.30 \\
Kelompok 4 & {$[25][8][11][29][17]$} & 0.45 \\
Kelompok 5 & {$[26][32][38][27][24]$} & 0.63 \\
Kelompok 6 & {$[7][28][15][39][4]$} & 0.38 \\
Kelompok 7 & {$[18][5][22][20][23]$} & 0.40 \\
Kelompok 8 & {$[34][35][14][36][37]$} & 0.32 \\
\hline
\end{tabular}

Pembentukan kelompok secara acak yang dapat dilihat pada Tabel 2 akan digunakan sebagai populasi awal dalam algoritma genetika. Algoritma akan mencari nilai fitness terbaik untuk dipilih sebagai populasi baru. Nilai fitness dianggap optimal jika memenuhi atau mendekati nilai dari target. Target ditentukan berdasarkan distribusi normal nilai SKPL tiap kelas. Tabel distribusi normal kelas1 dengan jumlah mahasiswa adalah 40 mahasiswa dapat dilihat pada Tabel 3.

Tabel 3. Distribusi Normal Nilai Tugas Kelas-I

$\begin{array}{cccc}\text { Nilai Huruf } & \text { Kategori Nilai } & \text { Jumlah Mahasiswa } & \text { Distribusi Minimum Siswa } \\ \text { A, AB } & \text { Baik } & 15 & 2 \\ \text { B, BC } & \text { Sedang } & 18 & 3 \\ \text { C,D,E } & \text { Kurang } & 7 & 0\end{array}$

Tabel 3 menunjukkan bahwa distribusi normal untuk sebuah kelompok tim proyek perangkat lunak adalah minimal ada 2 siswa kategori baik. Jadi, setidaknya ada 2 siswa dengan predikat nilai $\mathrm{A}$ atau $\mathrm{AB}$ berada di setiap kelompok tim proyek. Jika dihitung mengunakan formula (1), maka nilai fitness yang diperoleh adalah 0.30. Target yang digunakan dalam eksperimen ini adalah 0.30. Jika diperhatikan pada Tabel 2, ada 4 kelompok yang memiliki rentang jauh dengan target. Artinya, kelompok tersebut memiliki distribusi siswa yang kurang seimbang. Ada kemungkinan satu kelompok tidak memiliki siswa kategori "Baik".

Crossover adalah pertukaran antar dua kromosom terbaik untuk menghasilkan generasi baru. Pada eksperimen ini menggunakan teknik crossover one point. Teknik ini akan menukarkan bagian belakang kromosom dengan bagian depan kromosom lain, tujuannya adalah untuk mendapat offspring baru guna mendapat kromosom yang terbaik dari kromosom sebelumnya. Tingkat pertukaran antar kromosom dapat diatur dengan probabilitas dengan range 0.1-1.0. Pada eksperimen ini probabilitas crossover (pc) yang digunakan adalah 0.5 dan 0.6.

Mutasi adalah pertukaran allele dengan allele lainnya dalam satu kromosom. Teknik mutasi yang digunakan adalah swap yaitu pertukaran dengan cara menukar posisi pada allele. Misalnya, allele 3 ditukar dengan allele di posisi 5. Tingkat pertukaran pada mutasi juga dapat diatur intensitas pertukarannya. Hanya saja, pada eksperimen ini pertukaran mutasi tidak akan merubah nilai fitness karena hanya merubah posisi allele namun nilainya tetap sama. Tahap akhur adalah menemukan populasi baru dari pemilihan 2 (dua) kromosom terbaik (parent). Parent akan dikembalikan ke populasi awal untuk dihitung kembali agar menemukan kromosom yang optimal.

Eksperimen pada penelitian ini menggunakan pendekatan kuantitatif. Hasil penelitian akan dianalisis yang dapat ditampilkan dalam bentuk grafik. Tujuannya untuk mengetahui bahwa algoritma telah memberikan solusi optimal dalam pembentukan kelompok tim proyek perangkat lunak. Penelitian dilaksanakan dalam jangka waktu 3 bulan dimulai dari awal Dsember 2019 sampai Februari 2020. Obyek penelitian adalah fakultas ilmu komputer Universitas Dian Nuswantoro. 


\section{HASIL DAN PEMBAHASAN}

Penelitian ini menerapkan algoritma genetika untuk menemukan solusi optimal dalam pembentukan kelompok secara dinamis. Beberapa peneliti juga menggunakan algoritma genetika dalam menemukan solusi optimal pada proses pembelajaran seperti algoritma genetika digunakan untuk kasus optimasi pengajaran (Shukla, Pippal, \& Chauhan, 2019), prediksi peningkatan kemampuan siswa (Farissi \& Dahlan, 2020), dan pembentukan formasi siswa pada aplikasi kolaborasi dengan mengguanakan website (Krouska, Troussas, \& Virvou, 2020). Dalam tim proyek perangkat lunak, mahasiswa akan diarahkan dalam 2 (dua) percobaan. Percobaan pertama berupa pengelompokan mahasiswa dengan menggunakan data dari nilai SKPL. Percobaan kedua berupa pengelompokan ulang dengan menggunakan nilai dari tugas pada percobaan pertama. Percobaan pertama dilaksanakan selama 6 minggu dengan komposisi awal tim proyek dibentuk secara random oleh instruktor. Kelompok tersebut digunakan untuk membangkitkan inisial awal populasi. Penentuan populasi merupakan generator dalam pembentukan generasi populasi awal pada algoritma genetika (Garshasbi, Mohammadi, Graf, Garshasbi, \& Shen, 2019). Probabilitas crossover (pc) digunakan sebagai penentu dalam pembentukan kromosom baru (Lambora, Gupta, \& Chopra, 2019). Dalam hal ini, pc digunakan untuk mengganti kromosom lama dengan kromosom baru sesuai dengan tingkat probabilitasnya. Pada percobaan pertama ditentukan bahwa populasi berjumlah 100 populasi, probabilitas crossover adalah 0.5 dan 0.6 .

Hasil pada percobaan pertama, variasi anggota dalam kelompok tim proyek dibentuk sebanyak 100 variasi (100 populasi). Berdasarkan populasi tersebut diperoleh hasil yang dapat dilihat pada Tabel 4.

Tabel 4. Hasil Eksperimen I

\begin{tabular}{lll}
\hline Parameter & $\mathrm{pc}(0.5)$ & $\mathrm{pc}(0.6)$ \\
\hline Fitness Terbaik & 0.30 & 0.30 \\
Rata-rata Nilai Fitness & 0.38 & 0.35 \\
\hline
\end{tabular}

Nilai fitness digunakan sebagai fungsi untuk menentukan seberapa optimal kandidat solusi yang diciptakan. Dalam hal ini, kualitas formasi tim dapat ditentukan menggunakan nilai fitness. Penggunaan nilai fitness pada algoritma genetika dapat menilai keseimbangan formasi tim (Chen \& Kuo, 2019). Pada Tabel 4 menunjukkan bahwa algoritma mendapatkan hasil optimal dengan probabilitas crossover 0.6 dan nilai fitness sesuai dengan target yaitu 0.30 .

Operator crossover digunakan sebagai penentu frekuensi dalam pertukaran antar kromosom untuk menghasilkan kromosom baru (Shih, Gunarathne, Ochirbat, \& Su, 2018). Sebagai contoh Chen menggunakan two point crossover untuk menciptakan kromosom baru dari pertukaran kromosom basis dengan kromosom input (Chen, Chen, Lin, \& Wu, 2019). Adanya perbedaan tingkat intensitas pertukaran pada tahap crossover mempengaruhi hasil kerja algoritma genetika. Pada probabilitas crossover 0.6 mengalami peningkatan rata-rata nilai fitness yaitu sebesar 0.03 dari probabilitas crossover 0.5 . Selain itu, struktur pembentukan kelompok juga menghasilkan tim proyek yang sesuai atau mendekati dengan distribusi normal (Tabel 3). Berikut struktur kelompok dengan kromosom terbaik

Dari Tabel 5 dapat disimpulkan bahwa algoritma mampu memberikan solusi yang lebih optimal dibandingkan dengan pembentukan kelompok secara acak. Hasil menunjukkan bahwa $75 \%$ komposisi kelompok sesuai atau mendekati distribusi normal minimum (target) yang ditentukan. Jika dilihat pada Gambar 2, grafik persebaran mahasiswa pada tiap kelompok menunjukkan bahwa persebaran mahasiswa kategori dengan kategori "Baik" dan "Sedang" cenderung telah merata. Hanya ada 2 kelompok yang persebarannya melebihi distribusi normal yaitu kelompok 2 dan kelompok 8. 
48 - Jurnal Inovasi Teknologi Pendidikan

Tabel 5. Struktur Pembentukan Kelompok dengan Probabilitas Crossover 0,6

\begin{tabular}{clc}
\hline Kelompok & Daftar Siswa & Nilai Fitness \\
\hline 1 & {$[10][7][16][1][12]$} & 0.38 \\
2 & {$[3][2][9][31][40]$} & 0.31 \\
3 & {$[21][8][33][29][13]$} & 0.38 \\
4 & {$[35][30][11][19][17]$} & 0.39 \\
5 & {$[36][28][38][39][24]$} & 0.30 \\
6 & {$[26][32][22][27][4]$} & 0.55 \\
7 & {$[18][25][15][6][37]$} & 0.30 \\
8 & {$[34][5][14][20][23]$} & 0.40 \\
\hline
\end{tabular}

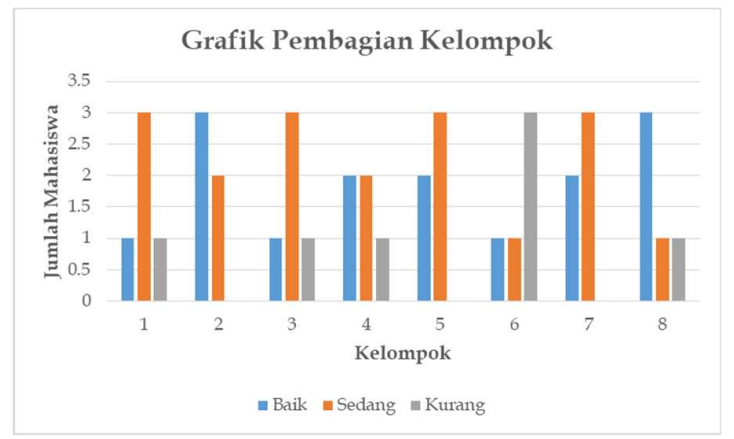

Gambar 2. Grafik Pembagian Kelompok

Pada Gambar 2 grafik persebaran mahasiswa pada tiap kelompok menunjukkan bahwa persebaran mahasiswa dengan kategori "Baik" dan "Sedang" merata. Hanya ada 2 kelompok yang persebarannya melebihi distribusi normal yaitu kelompok 2 dan kelompok 8. Pada percobaan kedua, dilaksanakan selama 5 minggu dengan komposisi tim proyek berdasarkan percobaan pertama. Data nilai yang digunakan adalah nilai pada penugasan pertama. Inisial populasi membangkitkan 100 populasi dengan pengaturan probabilitas crossover sama seperti percobaan pertama. Hanya saja, target pada percobaan kedua berbeda karena menggunakan data nilai yang berbeda. Target distribusi normal pada percobaan kedua adalah sebagai berikut:

Tabel 6. Distribusi Normal menggunakan Nilai Tugas Pertama

\begin{tabular}{cccc}
\hline Nilai Huruf & Kategori Nilai & Jumlah Mahasiswa & Distribusi Minimum Siswa \\
\hline A, AB & Baik & 23 & 3 \\
B, BC & Sedang & 14 & 2 \\
C,D,E & Kurang & 3 & 0 \\
\hline
\end{tabular}

Berdasarkan pada Tabel 6, dapat dihitung bahwa target nilai fitness adalah 0.27 dengan persebaran minimum mahasiswa kategori "Baik" adalah 3 dan "Sedang" adalah 2. Hasil percobaan kedua dapat dilihat pada Tabel 7.

Tabel 7. Hasil Eksperimen II

\begin{tabular}{lll}
\hline Parameter & pc $(0.5)$ & pc $(0.6)$ \\
\hline Fitness Terbaik & 0.27 & 0.27 \\
Rata-rata Nilai Fitness & 0.38 & 0.37 \\
\hline
\end{tabular}

Pada Tabel 7 menunjukkan bahwa pembentukan kelompok menghasilkan nilai fitness lebih baik dari percobaan pertama. Hal ini dikarenakan mahasiswa telah mengalami peningkatan nilai individu. Dapat dibandingkan pada Tabel 3 dan Tabel 6. Jumlah mahasiswa dengan kategori "Baik" 
meningkat 8 mahasiswa dan jumlah mahasiswa kategori "Kurang” berkurang 4 mahasiswa. Adanya peningkatan nilai fitness menunjukkan struktur persebaran mahasiswa dalam tim proyek juga lebih seimbang. Persebaran mahasiswa pada kategori "Baik" lebih merata jika dibandingkan dengan percobaan pertama. Pada Gambar 3 menunjukkan bahwa, batang grafik berwarna biru menampilkan persebaran mahasiswa kategori "Baik" merata sebanyak $87.5 \%$. Sedangkan untuk persebaran mahasiswa kategori "Sedang" sebanyak 75\%.

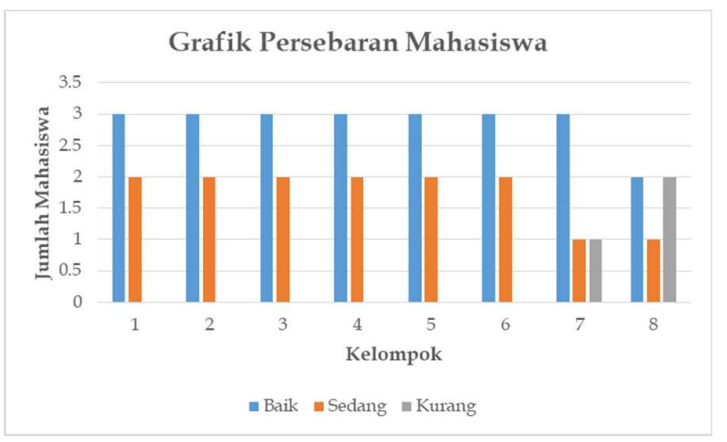

Gambar 3. Grafik Persebaran Mahasiswa pada Tim Proyek

Dari hasil percobaan diatas dapat diambil kesimpulan bahwa algoritma genetika mampu memberikan solusi optimal terhadap pembentukan kelompok tim proyek perangkat lunak secara dinamis. Selain itu, pembentukan kelompok secara dinamis mampu meningkatkan nilai individu mahasiswa. Mahasiswa mampu berkomunikasi dan diskusi interaktif dengan anggota lainnya meskipun tidak mengenal satu sama lain. Wilson menyatakan bahwa komunikasi efektif dapat meningkatkan kerja kolaborasi antar anggota (Wilson, Brickman, \& Brame, 2018). Peneliti lain juga menyatakan bahwa komunikasi efektif dapat mendorong interaksi antar individu dalam kerja tim (Noguera, Guerrero-Roldán, \& Masó, 2018). Peningkatan 12.5\% (5 dari 40 siswa) pada jumlah siswa kategori "Baik" menunjukkan bahwa mahasiswa juga mampu mengikuti materi diskusi yang diberikan oleh instruktor dan mampu berkolaborasi dengan anggota tim lainnya.

\section{SIMPULAN}

Pada penelitian ini mengusulkan formasi kelompok dinamis menggunakan algoritma genetika dalam mendukung pembentukan tim proyek perangkat lunak. berdasarkan studi pustaka, algoritma genetika dapat digunakan untuk mendukung formasi kelompok dinamis. Hasil eksperimen pertama dan kedua menunjukkan bahwa algoritma genetika dapat membantu pembentukan kelompok tim proyek secara seimbang. Tingkat keberhasilan algoritma genetika adalah $87.5 \%$ dengan pengaturan probabilitas crossover 0.6 dan inisial populasi adalah 100 populasi. Hal ini membuktikan bahwa algoritma genetika dapat membantu pembentukan kelompok tim proyek perangkat lunak secara dinamis.

Pembentukan kelompok secara dinamis mampu meningkatkan kemampuan individu mahasiswa pemula. Pada eksperimen, berdasarkan hasil penugasan mahasiswa pada proyek perangkat lunak, pendekatan dynamic group formation mampu meningkatkan nilai mahasiswa pemula. Percobaan kedua menunjukkan bahwa mahasiswa dengan kategori "Baik" meningkat 8 mahasiswa dari pembentukan kelompok secara acak. Hal ini membuktikan bahwa 8 mahasiswa yang sebelumnya di kategori "Sedang" atau "Kurang" telah meningkat ke kategori nilai "Baik". Beberapa mahasiswa mampu meningkatkan nilainya dalam penugasan tim proyek.

Tujuan utama dari penelitian ini adalah memberikan alternatif dalam pembentukan tim proyek mahasiswa pada matakuliah PPL. Hasil eksperimen telah membuktikan bahwa pendekatan dan algoritma yang digunakan mampu membentuk tim proyek secara adil dan meningkatkan kemampuan mahasiswa. Pada tim proyek selanjutnya (PPL kedepan) tidak ada pembentukan tim secara homogen dan/atau pemilihan anggota secara acak atau menggunakan metode self-select. 
Tahap eksperimen masih menunjukkan adanya kekurangan. Masih ada kelemahan 12.5\% persebaran siswa belum merata. Masih ada 1 kelompok yang memiliki komposisi anggota diluar target distribusi normal yang ditentukan. Pada penelitian selanjutnya, perlu dilakukan eksperimen lanjutan guna mengoptimalkan kerja algoritma genetika dengan penambahan mahasiswa, pengaturan populasi, formula untuk menentukan pengaturan crossover yang sesuai dan penggunaan teknik mutasi lain untuk mendapatkan kromosom atau offspring yang terbaik..

\section{DAFTAR PUSTAKA}

Amara, S., Macedo, J., Bendella, F., \& Santos, A. (2016). Group formation in mobile computer supported collaborative learning contexts: A systematic literature review. Journal of $\begin{array}{lllll}\text { Educational Technology } \quad \& \quad \text { Society, } & \text { 19(2), }\end{array}$ doi:https://doi.org/10.2307/jeductechsoci.19.2.258

Chen, C. H., Chen, Y. H., Lin, J. C. W., \& Wu, M. E. (2019). An effective approach for obtaining a group trading strategy portfolio using grouping genetic algorithm. IEEE Access, 7, 7313 7325. doi:https://doi.org/10.1109/ACCESS.2018.2889737

Chen, C. M., \& Kuo, C. H. (2019). An optimized group formation scheme to promote collaborative problem-based learning. Computers and Education, 133, 94-115. doi:https://doi.org/10.1016/j.compedu.2019.01.011

Dascalu, M.-I., Dumitrache, A.-M., Coman, M., \& Moldoveanu, A. (2015). Group maker tool for software engineering projects. Procedia-Social and Behavioral Sciences, 203, 102-108. doi:https://doi.org/10.1016/j.sbspro.2015.08.266

Fahmi, F. Z., \& Nurjanah, D. (2018). Group formation using multi objectives ant colony system for collaborative learning. Proceeding of the Electrical Engineering Computer Science and Informatics, 5(1), 696-702. doi:https://doi.org/10.11591/eecsi.v5.1711

Farissi, A., \& Dahlan, H. M. (2019, September). Genetic algorithm based feature selection for predicting student's academic performance. Paper presented at International Conference of Reliable Information and Communication Technology, Johor, Malaysia. doi:https://doi.org/10.1007/978-3-030-33582-3_11

Garshasbi, S., Mohammadi, Y., Graf, S., Garshasbi, S., \& Shen, J. (2019). Optimal learning group formation: A multi-objective heuristic search strategy for enhancing inter-group homogeneity and intra-group heterogeneity. Expert Systems with Applications, 118, 506521. doi:https://doi.org/10.1016/j.eswa.2018.10.034

Krouska, A., Troussas, C., \& Virvou, M. (2020). Applying genetic algorithms for student grouping in collaborative learning: A synthetic literature review. Intelligent Decision Technologies, 13(4), 395-406. doi:https://doi.org/10.3233/idt-190184

Lambora, A., Gupta, K., \& Chopra, K. (2019, February). Genetic algorithm-A literature review. Paper presented at 2019 International Conference on Machine Learning, Big Data, Cloud and Parallel Computing (COMITCon) (pp. 380-384), Faridabad, India.

Largent, D. L. (2016). Measuring and understanding team development by capturing self-assessed enthusiasm and skill levels. ACM Transactions on Computing Education, 16(2), 1-27. doi:https://doi.org/10.1145/2791394

Noguera, I., Guerrero-Roldán, A. E., \& Masó, R. (2018). Collaborative agile learning in online environments: Strategies for improving team regulation and project management. Computers and Education, 116, 110-129. doi:https://doi.org/10.1016/j.compedu.2017.09.008

Pedersen, J. M., Kuran, S., Frick, J., \& Mank, L. (2016). Colibri: An international blended learning experience based on real-world problems. Paper presented at 8th International Symposium on Project Approaches in Engineering EducationInternational Symposium on Project Approaches in Engineering Education (pp. 259-268), University of Minho. 
Rahman, H., Roy, S. B., Thirumuruganathan, S., Amer-Yahia, S., \& Das, G. (2019). Optimized group formation for solving collaborative tasks. VLDB Journal, 28(1), 1-23. Doi:https://doi.org/10.1007/s00778-018-0516-7

Rahmawati, R. N., \& Narsa, I. M. (2019). Penggunaan e-learning dengan Technology Acceptance Model (TAM). Jurnal Inovasi Teknologi Pendidikan, 6(2), 127-136. doi:https://doi.org/10.21831/jitp.v6i2.26232

Shih, T. K., Gunarathne, W. K. T. M., Ochirbat, A., \& Su, H. M. (2018). Grouping peers based on complementary degree and social relationship using genetic algorithm. ACM Transactions on Internet Technology, 19(1), 1-29. https://doi.org/10.1145/3193180

Shukla, A. K., Pippal, S. K., \& Chauhan, S. S. (2019). An empirical evaluation of teaching-learningbased optimization, genetic algorithm and particle swarm optimization. International $\begin{array}{llll}\text { Journal of Computers and } & \text { Aplications, }\end{array}$ doi:https://doi.org/10.1080/1206212X.2019.1686562

Tseng, H. E. J. J. (2016). Blended versus traditional course delivery: Comparing students' motivation, learning outcomes, and preferences. Quarterly Review of Distance Education, 17(1), 43-52.

Utomo, D. W., Kurniawan, D., \& Sani, R. R. (2020). Pemodelan Algoritma Genetika dalam Pengelompokan Siswa Pada Kolaborasi. Seminar Nasional Dinamika Informatika 2020 Universitas PGRI Yogyakarta, 148-152.

Utomo, D. W., Subhiyakto, E. R., \& Ahmad, S. (2015). Tool Enhancement For Collaborative Software Engineering Education. Seminar Nasional Teknologi Informasi dan Komunikasi 2015 (SENTIKA 2015), 9-16.

Vivian, R., Tarmazdi, H., Falkner, K., Falkner, N., \& Szabo, C. (2015). The development of a dashboard tool for visualizing online teamwork discussions. 2015 IEEE/ACM 37th IEEE International Conference on Software Engineering, 2, 380-388. doi:https://doi.org/10.1109/ICSE.2015.170

Wijaya, M. M. J., Utomo, D. W., \& Kurniawan, D. (2019, December). Implementing dynamic group formation in web-based collaborative learning for high school. Paper presented at 2019 International Seminar on Research of Information Technology and Intelligent Systems (ISRITI), Yogyakarta, Indonesia. doi:https://doi.org/10.1109/ISRITI48646.2019.9034625

Wilson, K. J., Brickman, P., \& Brame, C. J. (2018). Group work. CBE Life Sciences Education, 17(1), 1-5. doi:https://doi.org/10.1187/cbe.17-12-0258

Wu, J. (2019, July). Online collaborative learning of a mixed team: A case study of hotel and tourism students from varied education backgrounds. Paper presented at 3rd International Conference on Education and Multimedia Technology, Nagoya, Japan. doi:https://doi.org/10.1145/3345120.3345137

Yamagata-Lynch, L. C. (2014). Blending online asynchronous and synchronous learning. International Review of Research in Open and Distributed Learning, 15(2), 189-212. doi:https://doi.org/10.19173/irrodl.v15i2.1778

Yunis, R., \& Telaumbanua, K. (2017). Pengembangan E-Learning Berbasiskan LMS untuk Sekolah, Studi Kasus SMA/SMK di Sumatera Utara. Jurnal Nasional Teknik Elektro dan Teknologi Informasi (JNTETI), 6(1), 32-36.

Zheng, Z., \& Pinkwart, N. (2014). Dynamic re-composition of learning groups using PSO-based algorithms. Proceedings of the 7th International Conference on Educational Data Mining, $3,357-358$. 